\title{
Regulatory Changes and Productivity of the Banking Sector in the Indian Sub-continent
}

\author{
ShabBar JAFFry, YASEen GHUlam, SeAn PAscoe, and JoE CoX
}

\section{INTRODUCTION}

Efficiency plays an important role in the operation of firms. If firms are pursing a policy of shareholder wealth maximisation, this implies that maximum efficiency is extracted from a firm's resources during the production process, or that the minimum quantity of inputs is used to achieve a desired level of output.

Studies on efficiency in firms have been relatively forthcoming and include work on technical efficiency in the Japanese manufacturing sector [Hitomi (2004)], the UKCS Petroleum Industry [Kashani (2005)] and labour efficiency of the Indian farming industry [Kumbhakar (1996)].

However, there is little in the way of research conducted on efficiency within the banking sector, and even less on the banking sectors of developing economies [Berger and Humphry (1997)]. This is unfortunate, as banks and financial institutions are the most important organisations in overall financial intermediation and economic acceleration of a country. Banks play a significant role in converting deposits into productive investment [Podder and Mamun (2004)]. For this reason, the study of banking in developing economies entails a greater significance.

This paper seeks to examine the efficiency of the banking sectors in India, Pakistan and Bangladesh, over the period 1993-2001, a period which is also characterised in the Indian sub-continent as a period of significant reform, deregulation and liberalisation in each country's respective banking sectors.

This process of liberalisation and modernisation is vitally important in this particular case. Because of its unique position within the framework of an economy, the banking industry of a country is invariably more heavily regulated and scrutinised than other industries. This trend is particularly apparent in developing economies, where banks tend to exhibit poor performance as a result of overly prohibitive regulation [Kumbhakar and Sarkar (2003)]. Thus, tests of efficiency can be made more meaningful by including some comparison of efficiency both pre and post modernisation. However, as subsequently outlined in the paper, prior studies

Shabbar Jaffry, Yaseen Ghulam, Sean Pascoe, and Joe Cox are based at the Department of Economics, Portsmouth Business School, University of Portsmouth, Portsmouth, UK.

Authors' Note: We are thankful for all comments made by the participants of the 21st AGM and Conference of the PSDE, and especially the discussant of the paper. 
into technical efficiency both pre and post deregulation have displayed mixed results in terms of the impact such measures have had upon efficiency. Expectations upon the result of the modernisation and deregulation of the banking industries in the countries of the Indian sub-continent are therefore unclear.

\section{COUNTRY CASE STUDIES}

In the 1980s and 1990s, a large number of economies undertook extensive processes of liberalisation and modernisation, particularly with respect to financial and banking industries. The developed world led the way in this respect, with most notably the USA experiencing productivity and efficiency increases as a result of the relaxation of the country's regulatory environment. Developing countries have also experienced a degree of de-regulation. The Indian sub-continent of South Asia is a prime example of such a trend, with a majority of major revisions to the operation of their respective financial centres coming in the early 1990s.

India is a country in the heart of this sub-continent. The country was a part of the British Empire until it was recognised as a republic in 1947. India has shed its dependence on agriculture since it has become a republic. Now, some of the fastest growing industries include IT, textiles and mining.

Banking has also become an emerging industry in the modern era. The Bengal Bank was the first British patronised modern bank in India, and was established in 1784 . Today, there are more than 458,782 institutions channelling credit into the various areas of the economy. The banking sector in India has historically been highly regulated, but gradually the restrictions imposed by such a regime are being lifted. The first 'wave' of reform began in 1969, when fourteen major banks were nationalised. Six more commercial banks were nationalised in 1980. A number of new reforms were introduced during the period 1992-1997. These include a reduction in reserve requirements, privatisation of public sector banks, interest rate deregulation, and an effort to remove barriers to market entry. As such, the Indian banking sector is currently in a transitional phase. Public sector banks are also trying to reduce manpower, non-performing assets and government equity. Foreign direct investment ceilings have also increased under the reforms.

This series of actions has brought about a number of trends, including an increased take up of technology among private sector banks, and increased tendency toward mergers and consolidations among Indian private banks, and a general streamlining, involving a reduction in manpower, non-performing assets and government equity. There has also been a trend of banks diversifying their portfolios in order to achieve better risk management.

Since the reforms began in the early 1990s, public sector banks in India have found it extremely difficult to compete against private sector banks and foreign banks. In response to this, public sector banks are in the process of cutting excessive use of manpower and non-performing assets, as is their right under the new reforms. Other 
responses to deregulation and modernisation have included an increase in the volume of merger and acquisition activity, an increase in the use of technology, an increased usage of diversification and more sophisticated risk management techniques.

Pakistan neighbours India in the sub-continent, and has historically seen similar trends emerge in terms of banking to India. As a distinct country, Pakistan gained independence from the British Empire in 1947 and a Pakistani central bank established in 1948 . Whilst initially the country was initially very poor, with a significant portion of national wealth generated from agricultural activities, in the modern era the country's growth rate has been consistently above the world average. Pakistan achieved a real GDP growth rate of 5.1 percent in 2002-03, which made it the second fastest growing economy in the world.

However, in the 1990s, the country experienced an economic slowdown as a result of poor policy-making where the activities of Pakistani banks were focused around subsidising the fiscal deficit, serving a few large corporations and engaging in trade financing. Additionally the financial system suffered from political interference in lending decisions and also in the appointment of banking managers.

The wave of deregulation and financial modernisation experienced in Pakistan during the late 1990s was directly in response to some of these problems. These included strengthening of prudential regulations, a market driven exchange rate system, and the appointment of independent persons to the board of directors of nationalised banks and an enhanced capital adequacy requirement and a reduction in the restriction on branching.

Similar ramifications were observed in the case of the Pakistani deregulation as were seen in India. Again, there was a significant increase in merger and acquisition activity, as well as an expansion of branching networks by private and foreign banks. There has also been the introduction of new technologies to aid in the process of automation and the exploitation of the growing consumer finance market, and a reduction in the volume of non-performing loans.

Reform of the banking sector is now entering a second phase, where local banks are being asked to raise their paid capital, follow a maximum disclosure requirement and make full provision against non-performing loans. Foreign banks have thrived in the past due to significant investments in technology, including ATMs and credit cards. However, at the current point in time, many foreign banks are selling to local banks [Kazmi (2002)]. The fall in fortunes of foreign banks can be put down to, in part, an increased confidence in privatised domestic banks.

Bangladesh is a country in the East of the Indian sub-continent (the former Bengal region). Bangladesh has remained relatively under-developed when compared to India and Pakistan. Rice and garment exporting remain the most important industries in the country. Bangladesh has found it difficult to achieve the stability from which to promote the levels growth that India and Pakistan have achieved, largely as a result of repeated natural disasters-most notably flooding. 
The Bangladeshi banking sector, relative to the size of its economy is comparatively larger than many economies of similar level of development and per capita income. The total size of the sector at 26.54 percent of GDP dominates the financial system [Sayeed, et al. (2002)]. Despite its size, the Bangladeshi banking sector has historically been underdeveloped. Bangladesh Bank, the central bank of Bangladesh, was established in 1971. The formation of the country had had caused those banks that were inherited to be quickly merged and nationalised.

In the early 1990s, faced with a high proportion of non-performing loans, and frequent accusation of corruption, there was a shift in policy by those responsible for regulating the Bangladeshi banking sector. As with both India and Pakistan, Bangladesh has too embarked upon a period of significant deregulation, again beginning in the early 1990s. Methods employed in this instance include a general strengthening of the regulatory environment, enforcement of loan classification, a recapitalisation and privatisation of public sector commercial banks, as well as a gradual reduction of political interference in lending priorities.

These measures have resulted in Bangladeshi banks attempting to diversify and strengthen their portfolios (especially the case with commercial banks), an improvement in the non-performing loan ratio and a significant rise in interest related income for all Bangladeshi banks. However, overall earning and profitability have remained quite unstable despite the programme of reforms.

\section{FINDINGS OF OTHER PAPERS}

As previously stated, in the 1980s and 1990s, a large number of developing economies undertook extensive processes of liberalisation and modernisation, particularly with respect to financial and banking industries. The developed world led the way in this respect, with most notably the USA experiencing productivity and efficiency increases as a result of the relaxation of the country's regulatory environment.

A number of studies have documented this phenomenon within various American industries, including air transportation, telecommunication and freight transportation. Theory does not dictate a clear expected result of deregulation and modernisation in the banking sector in terms of efficiency gains, as the consequences of deregulation may depend on industry conditions prior to the deregulation process, as well as the type of deregulation employed [Berger and Humphrey (1997)].

As a result of this, studies of efficiency in banking have not displayed as clear-cut trends as are illustrated in the above examples. US studies in particular show that productivity within the banking sector decreased following regulation [Berger and Mester (2001)]. Wheelock and Wilson (1999) concurred and observed declining efficiency and productivity within the US banking sector over time (but did not look at any regulatory changes during that period). However, Bauer, et al. (1993) observed that interest rate competition between US banks has not significantly changed post-deregulation. 
In contrast, there have been several studies that point to deregulation and modernisation having a positive effect upon efficiency. Gilbert and Wilson (1998) showed that Korea's process of privatisation has resulted in its increased output and productivity. These results have also been observed in banking studies. Berg, et al. (1992) find that deregulation on volume and interest rate of bank lending led to an improvement in the efficiency of Norwegian banking. Zaim (1995) found that a similar trend existed in the case of the Turkish banking sector.

There is a debate as to whether or not increased merger and acquisition activity-frequently a by-product of deregulation and liberalisation-has a significant effect upon efficiency. For example, Resti (1998) analyses 67 bank mergers in Italy, and found that larger firms who are less efficient still tend to engage in merger activity as the buyers, with a view to making efficiency gains. Christopoulos, et al. (2002) suggest that there is an incentive to conduct merger activity, in that the buyer will obtain cost and efficiency gains, as a great majority of banks involved in mergers and acquisitions exhibited increasing returns to scale. Cuesta and Oreia (2002) use a stochastic output distance function to accommodate multiple output technology for Spanish savings banks during the period 1985-1998. The study concludes that merged firms will be more efficient than non-merged firms.

Bonnaccorsi di Patti and Hardy (2005) examined the efficiency of the Pakistani Banking sector in isolation. Over the period of modernisation, they observe an increase in efficiency as a result of the new competitive environment resulting from the first round of deregulation. It was also found that new private banks sometimes outperformed foreign banks in terms of efficiency.

There are a number of competing approaches to the measurement of efficiency.

For example, Atkinson and Primon (2002) formulate shadow distance and shadow cost systems as approaches to estimating firm technology, allocative efficiency, technical efficiency, and productivity growth, using panel data for 43 US utilities over 37 years. The two models diagnose an over-use of capital relative to labour and energy and the under-use of energy relative to labour.

Cooper, et al. (1995) study the impact of the 1978 Chinese economic reforms on the Textiles, Chemicals and Metallurgical Industries, using data covering the period of 1966-1988. In all three industries, there was found to be a dramatic increase in efficiency, which was manifest almost immediately following deregulation.

Mendes and Rebello (1999) study the Portuguese banking sector, and illustrate that deregulation in that specific case did not lead to an increase in cost efficiency, but rather to technological regress.

Fukuyama and Weber (2002) use panel data on Japanese banks over the period of 1992-1996, productivity growth is measured and decomposed into changes in output allocative efficiency, input technical efficiency and technical change. The 
study concludes that Japanese banks experienced productivity declines over the period of analysis and that each bank could have used somewhere between 78-93 percent of actual inputs if they had chosen the most efficient, revenue maximising combination of outputs.

Khumbhakar, et al. (2001) use a short run profit function to investigate the effects of deregulation on the performance of Spanish savings banks over the period 1986 to 1995 . The study concludes that mean output losses due to technical inefficiency increased post deregulation, suggesting that struggle to keep pace with the changing banking environment. The authors also find that branch expansion is an effective competitive strategy (as banks which employed this strategy showed technical progress every year).

Stochastic frontier estimation is frequently used in efficiency analysis. Models of this nature usually estimate a usage function for one or more factors of production, giving the minimum amount of that resource technically necessary to produce a given level of output. The difference between the 'frontier' and the actual in each specific case is equivalent to the individual level of relative inefficiency of that particular firm.

The use of stochastic frontier models has increased dramatically since early work by Shephard (1970), Aignes, et al. (1977) and Meeusent and Van den Broeck (1977). Contemporary examples of such studies are manifold. For example, Sena (2004) examines a sample of firms from the Italian manufacturing over the period 1989-1994 in order to establish whether financial constraints create an incentive for firms to improve efficiency over time. The study indicates that technical efficiency can be affected by the financial resources availability so that once a firm cannot have access to external financial resources, then it has an incentive to improve its technical efficiency.

Rossi (2001) uses a stochastic frontier approach to analyse the technical change in the post-privatisation period in the gas distribution sector in Argentina. They find that there is both a catching up effect and a shift in the frontier, which shows that the sector as a whole improved its efficiency post privatisation.

Heshmanti, et al. (1995) investigate the issues of technical efficiency in the Swedish pork industry during the period of 1976-1988. A stochastic frontier production model, with the underlying technology represented by a generalised Cobb-Douglas model is used. The study indicates that technical change is positive but declining during the period 1976-1980 turning into technical regress during the remaining period, 1981 to 1988.

Canhoto and Dermine (2003) tried to estimate the magnitude of efficiency gains in Portugal over the years 1990-1995, a period of significant financial deregulation following EU membership. The non-parametric DEA approach used in the study shows an improvement in efficiency for the overall sample over time, with the new banks dominating the old ones in terms of efficiency. The authors conclude 
that the creation of new banks is likely to accelerate the efficiency gains (if any) expected following a period of deregulation.

There have also been a number of studies investigating efficiency relative to the sizes of banks. Christopoulos, et al. (2002) estimate cost efficiency of the Greek banking system over the period 1993-1998 (a period where the country joined EMU and hence underwent a period of liberalisation and deregulation). The empirical results of this study show that larger banks are less efficient than smaller ones. Carvallo and Kasman (2005) estimate a stochastic common cost frontier using IBCA information for a panel of 481 banks from 16 Latin American countries. The results suggest the largest economies are the most inefficient and that very small and very large banks are significantly more inefficient than large banks.

\section{METHODOLOGY}

A three pronged approach to efficiency measurement within the Indian subcontinent is used for this study. These are the Malmquist Index, an output oriented DEA and a Panel Tobit Analysis of resultant DEA scores.

In the first instance, this study uses a Malmquist index [as outlined by Fare, et al. (1997)] to estimate TFP, efficiency change and technical change in the Indian sub-continent following respective periods of deregulation embarked upon in the early 1990s. The Malmquist index specified will be able to determine levels of change in productivity and technical efficiency between time periods. However, the method is non-transitive, and so cannot be used to estimate cumulative impacts over time.

The Malmquist index discussed above is calculated as follows [as outlined in Fare, et al. (1994)].

$$
m\left(u_{t}, x_{t}, u_{t+1}, x_{t+1}\right)=\left[\frac{d_{0}^{t}\left(u_{t+1}, x_{t+1}\right)}{d_{0}^{t}\left(u_{t}, x_{t}\right)} \times \frac{d_{0}^{t+1}\left(u_{t+1}, x_{t+1}\right)}{d_{0}^{t+1}\left(u_{t}, x_{t}\right)}\right]^{1 / 2}
$$

This formula can be further decomposed into efficiency and technical change as follows

$$
m\left(u_{t}, x_{t}, u_{t+1}, x_{t+1}\right)=\frac{d_{0}^{t+1}\left(u_{t+1}, x_{t+1}\right)}{d_{0}^{t}\left(u_{t}, x_{t}\right)}\left[\frac{d_{0}^{t}\left(u_{t+1}, x_{t+1}\right)}{d_{0}^{t+1}\left(u_{t+1}, x_{t+1}\right)} \times \frac{d_{0}^{t}\left(u_{t}, x_{t}\right)}{d_{0}^{t+1}\left(u_{t}, x_{t}\right)}\right]^{1 / 2} \ldots
$$

Where the first part of the equation (that which lies outside of the parenthesis) represents efficiency change and the second part (contained within the parenthesis) represents technical change.

The Malmquist index provides a measure of changes in total factor productivity (TFP) from year to year. The values are concentrated around 1, which 
implies no change. A TFP value which is greater than 1 implies an improvement, while a value less than 1 implies a decrease in productivity.

TFP is comprised of two parts-efficiency changes and technical change. The efficiency change relates to how the firms performed relative to the production frontier. An efficiency change which is greater than 1 implies that the firms are operating closer to the frontier than in the previous time period, while if the figure is less than 1 , the bank in question is operating further from the frontier. Technical change really just means a shift in the frontier. This can be affected by technology or also changes in the economic or regulatory environment. A technical change (TC) value which is less than 1 means the frontier has shifted inwards, while a TC value which is greater than 1 implies that the frontier has shifted outwards.

The Malmquist index can be estimated as a function of a set of distance functions, which, in turn, can be estimated using DEA. This is a methodology proposed, again, by Fare, et al. (1997). The index requires 4 DEA models to be estimated, which respectively specify efficiency in the current time period, $d_{0}^{t}\left(u_{t}, x_{t}\right)$; efficiency in the next time period, $d_{0}^{t+1}\left(u_{t+1}, x_{t+1}\right)$; efficiency of a firm operating in this time period relative to firms operating in the next time period, $d_{0}^{t+1}\left(u_{t}, x_{t}\right)$; and the efficiency of firms operating in the next time period relative to the frontier in this time period, $d_{0}^{t}\left(u_{t+1}, x_{t+1}\right)$. The TFP index is then calculated using Equation (1), above.

We have used an output orientation, which means we are estimating the frontier in terms of the maximum level of output that can be achieved with a given set of inputs. For this study, an alterative approach is to use an input orientationwhere the frontier is the minimum set of inputs required for a given level of output. We feel that use of the output orientation is more appropriate in this case.

The Malmquist index is estimated assuming constant returns to scale. This is not always a realistic assumption so we can also estimate efficiency with variable returns to scale. This can be resolved by simply adding another constraint to the DEA model. The equation used is an output orientated DEA model for $j$ banks; $m$ outputs ( $\mathrm{ujm}$ ) and $n$ inputs (xjm). The model is then expressed in a Constant Returns-to Scale (CRS) format in Equation (3) below.

$$
\begin{aligned}
& {\left[d_{0}^{t}\left(u_{t}, x_{t}\right)\right]^{-1}=\operatorname{Max} \quad \theta} \\
& \text { s.t. } \\
& \theta u_{0, m} \leq \sum_{j} z_{j} u_{j, m} \quad \forall m \\
& \sum_{j} z_{j} x_{j, n} \leq x_{0, n} \quad \forall n \\
& z_{j} \geq 0
\end{aligned}
$$


In addition, the equation can be presented in a Variable Returns to Scale (VRS) format by adding the following additional constraint.

$$
\sum_{j} z_{j}=1
$$

The Output oriented DEA specified will be used to compare all observations across the specified time period, and to resultantly estimate relative efficiency scores for each bank in each country across time.

\section{IV.1. Tobit Analysis}

Factors affecting the level of efficiency were examined using panel tobit analysis. Tobit analysis is required as the efficiency scores are censored at 1 . The set of variables used in the analysis, and a brief description of each is presented in Table 1. It is thought that the factors which would affect relative efficiency levels over time would be the type and characteristics of banks, country and macroeconomic effects and changes to the regulatory environment.

\section{DATA}

Panel data is taken from a selection of Pakistani, Indian and Bangladeshi banks, covering the period 1993-2001. ${ }^{1}$ As common in literature second stage Panel Tobit Regression [Davidson and MacKinnon (2004), p. 284-286] is used to explain the variation in efficiency score across different types of banks and over the years. For second stage TE VRS' (Technical Efficiencies with Variable Returns to Scale) are used as a dependent variable. It is thought that the factors which would affect relative efficiency levels over time would be the type and characteristics of banks, country and macroeconomic effects and changes to the regulatory environment.

Following Sathe (2003), ${ }^{2}$ two outputs and two inputs are used to calculate efficiency and productivity. The focus in choosing inputs and outputs is to capture the activities of banks as directly as possible. Thus the variables chosen to measure each bank's output are interest income (interest received on advances) and non-interest income (fee and commission income and income from other sources). The two inputs used to generate these outputs are interest cost (interest paid on deposits) and noninterest cost (overheads) expenses. The selection of variables is in line with the changing environment and the objectives of the banking industry in the post reform period. All inputs and outputs are translated into USD from respective local currencies, whereby the average exchange rate for the year in question is used. Table 1 presents the summary statistics of the data.

${ }^{1}$ The data was collected from the Bank Scope database and other sources. Unfortunately, a comparable data for three countries was only available for the period 1993-2001. However, this sample period covers the post deregulation period for all three countries.

${ }^{2}$ For detailed debate on the issue of the selection of inputs and outputs see [Berger and Humphrey (1992)]. 
Table 1

Summary Statistics of the Variables Used (in US\$)

\begin{tabular}{|c|c|c|c|c|c|}
\hline Variable & Obs & Mean & Std. Dev. & Min & Max \\
\hline & \multicolumn{5}{|c|}{ A. Overall } \\
\hline Interest Income & 898 & 179 & 359 & 0 & 3270 \\
\hline Non-interest Income & 898 & 29 & 65 & -9 & 824 \\
\hline Interest Cost & 898 & 118 & 211 & 0 & 1417 \\
\hline Overheads & 898 & 59 & 113 & 7 & 1055 \\
\hline \multirow[t]{2}{*}{ Total Assets (Business) } & 898 & 2134 & 4313 & 4 & 38380 \\
\hline & \multicolumn{5}{|c|}{ B. Pakistan } \\
\hline Interest Income & 191 & 101 & 193 & 0 & 1176 \\
\hline Non-interest Income & 191 & 35 & 103 & -9 & 824 \\
\hline Interest Cost & 191 & 65 & 113 & 0 & 567 \\
\hline Overheads & 191 & 50 & 112 & 7 & 1055 \\
\hline \multirow[t]{2}{*}{ Total Assets (Business) } & 191 & 1344 & 2388 & 29 & 12183 \\
\hline & \multicolumn{5}{|c|}{ C. Bangladesh } \\
\hline Interest Income & 167 & 34 & 50 & 0 & 271 \\
\hline Non-interest Income & 167 & 12 & 26 & 0 & 219 \\
\hline Interest Cost & 167 & 28 & 40 & 0 & 188 \\
\hline Overheads & 167 & 22 & 57 & 0 & 544 \\
\hline \multirow[t]{2}{*}{ Total Assets (Business) } & 167 & 601 & 821 & 10 & 4051 \\
\hline & \multicolumn{5}{|c|}{ D. India } \\
\hline Interest Income & 540 & 251 & 431 & 0 & 3270 \\
\hline Non-interest Income & 540 & 32 & 54 & -1 & 460 \\
\hline Interest Cost & 540 & 164 & 252 & 0 & 1417 \\
\hline Overheads & 540 & 74 & 122 & 3 & 761 \\
\hline Total Assets (Business) & 540 & 2885 & 5215 & 4 & 38380 \\
\hline
\end{tabular}

Table 2 is a summary of the variables that have been included in the model specification used to test for technical efficiency. Each variable is explained, and the derivation of each value outlined. The expected sign of each of the variables has also been listed. 
Table 2

Variables Used in the Panel Tobit Analysis

\begin{tabular}{|c|c|c|}
\hline Variable & Assumptions & $\begin{array}{l}\text { Expected } \\
\text { Sign }\end{array}$ \\
\hline \multicolumn{3}{|l|}{ Bank Characteristics } \\
\hline $\begin{array}{l}\text { Bank equity capital divided by total } \\
\text { assets }\end{array}$ & $\begin{array}{l}\text { Well-capitalised banks face lower bankruptcy cost. } \\
\text { This will translate into lower cost of funds and } \\
\text { higher efficiency. }\end{array}$ & +ve \\
\hline $\begin{array}{l}\text { Bank non earning assets divided by total } \\
\text { assets }\end{array}$ & $\begin{array}{l}\text { Presence of high non-interest earning assets } \\
\text { reduces the profitability and efficiency. Funds are } \\
\text { tied up usually in accordance to regulation. }\end{array}$ & -ve \\
\hline Bank net loans divided by total assets & $\begin{array}{l}\text { Higher lending will transform into higher } \\
\text { efficiency }\end{array}$ & +ve \\
\hline Bank deposits divided by total assets & $\begin{array}{l}\text { Higher deposits may increase the cost of funds and } \\
\text { reduction in efficiency }\end{array}$ & $-\mathrm{ve}$ \\
\hline $\begin{array}{l}\text { Bank overhead expenditure divided by } \\
\text { total assets }\end{array}$ & $\begin{array}{l}\text { Higher overheads eat into bank income and reduce } \\
\text { efficiency }\end{array}$ & $-\mathrm{ve}$ \\
\hline $\begin{array}{l}\text { Bank other operating income divided by } \\
\text { total assets }\end{array}$ & $\begin{array}{l}\text { Banks active in non-interest earning activities (fee } \\
\text { and commission) are likely to be more efficient }\end{array}$ & +ve \\
\hline Bank net income divided by total assets & $\begin{array}{l}\text { Higher return on assets translates into more } \\
\text { efficient bank }\end{array}$ & +ve \\
\hline Bank age (years) & $\begin{array}{l}\text { Older and more established banks are likely to be } \\
\text { more efficient }\end{array}$ & +ve \\
\hline \multicolumn{3}{|l|}{ Macroeconomic Indicators } \\
\hline Log of per capita GDP (in dollars) & An index of country economic development. & +ve \\
\hline GDP growth rate & $\begin{array}{l}\text { Higher growth translates into higher demand for } \\
\text { credit and higher efficiency }\end{array}$ & +ve \\
\hline Inflation rate (based on CPI) & $\begin{array}{l}\text { Banks obtain higher earnings in high inflationary } \\
\text { countries and should be more efficient }\end{array}$ & +ve \\
\hline $\begin{array}{l}\text { Real interest rate (interest rate minus } \\
\text { inflation rate) }\end{array}$ & $\begin{array}{l}\text { Increase in real interest rate increase spread. } \\
\text { Situation may be different, if deposit rates tied } \\
\text { down by deposit rate ceilings. }\end{array}$ & +ve \\
\hline Country share price index & $\begin{array}{l}\text { Boom in share prices may send positive signals and } \\
\text { boost demand for credit and higher efficiency }\end{array}$ & +ve \\
\hline \multicolumn{3}{|c|}{ Financial Structure Variables } \\
\hline $\begin{array}{l}\text { Total assets of largest three banks of the } \\
\text { country divided by total assets of the } \\
\text { banking sector of the country }\end{array}$ & $\begin{array}{l}\text { High concentration may lead to efficiency (relative } \\
\text { efficiency and structure conduct performance } \\
\text { model test) }\end{array}$ & +ve \\
\hline Log of total assets & $\begin{array}{l}\text { Scale effect variable. Larger size banks may be } \\
\text { more efficient }\end{array}$ & +ve \\
\hline Number of banks & $\begin{array}{l}\text { Higher number of banks may be negative factor } \\
\text { given the low demand for credit in developing } \\
\text { countries }\end{array}$ & -ve \\
\hline Bank credit divided by GDP & $\begin{array}{l}\text { Higher ratio is a proxy for intense competition. It } \\
\text { can lead to higher efficiency. }\end{array}$ & +ve \\
\hline $\begin{array}{l}\text { Stock market capitalisation divided by } \\
\text { GDP }\end{array}$ & $\begin{array}{l}\text { In more developed stock markets } \\
\text { complementarities between debt and equity may be } \\
\text { strong }\end{array}$ & +ve \\
\hline
\end{tabular}




\section{ESTIMATION AND EXPLANATION}

\section{VI.1. Efficiency and Total Factor Productivity Changes Over Time}

Initial estimations of the model using the data from all three countries combined identified a small number of observations that were either very efficient or very inefficient in each country (Figure 1). These resulted in the average efficiency being relatively low (less than 0.4). As the observations did not consistently correspond to the same single bank or set of banks, it is possible that there were some data errors. These may have been inaccurate sampling (i.e. the original data set may have been recorded inaccurately) or measurement errors (for example, if a bank had fully depreciated its capital assets then the noninterest costs would have been lower than a bank which was still depreciating its capital assets). It was decided that the outliers corresponding to very efficient and, more controversially, very inefficient banks (influential observations) should be excluded from the analysis, which is an option often exercised in DEA analysis). ${ }^{3}$ Therefore, the exclusion 'rule' was established, whereby banks that had initial TECRS estimates above 0.5 (i.e. the outliers) and less than 0.2 were dropped from the sample. This decreased the size of the sample from 1006 to 898, a reduction of just over 10 percent (Figure 1).

Fig. 1. Initial Distribution of Efficiency Scores

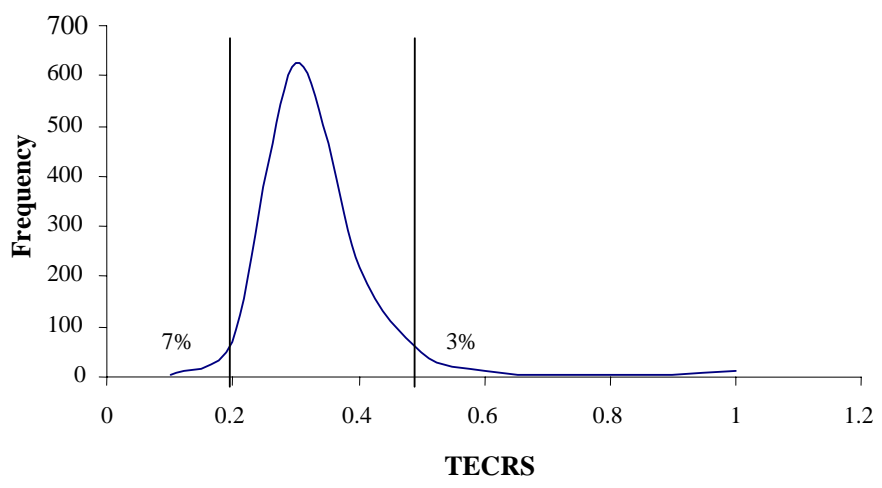

The data were initially combined (over both country and time) and the technical efficiency estimated for each observation. A VRS measure was used as this was more flexible. These efficiency scores were also subsequently used in the tobit analysis to estimate the factors that affect efficiency. The results displaying technical efficiency with variable returns to scale for each country in each year of the study can be observed in the Table 3 below. 
Table 3

Technical Efficiency Levels with Variable Returns to Scale

\begin{tabular}{lccccccccc}
\hline TEVRS & 1993 & 1994 & 1995 & 1996 & 1997 & 1998 & 1999 & 2000 & 2001 \\
\hline Pakistan & 0.760 & 0.815 & 0.744 & 0.745 & 0.673 & 0.665 & 0.679 & 0.705 & 0.755 \\
Bangladesh & 0.587 & 0.706 & 0.775 & 0.739 & 0.744 & 0.716 & 0.703 & 0.732 & 0.771 \\
India & 0.570 & 0.622 & 0.712 & 0.712 & 0.713 & 0.721 & 0.699 & 0.724 & 0.753 \\
Average & 0.669 & 0.739 & 0.730 & 0.724 & 0.709 & 0.708 & 0.696 & 0.722 & 0.757 \\
\hline
\end{tabular}

The above results indicate that the technical efficiency of Bangladeshi and Indian banks have generally increased over time. Pakistani banks appear to have experienced a different trend, as the above results show reduced levels of technical efficiency in the middle of the period of the data, although it should be noted that there has been a significant recovery in terms of the technical efficiency levels towards the end of the period. It is likely that this represents the effects of major reforms introduced within Pakistan during the latter part of the 1990s, particularly post 1997. It should also be noted that the average efficiency level in all three countries appears to be converging over time. This information can be seen graphically in Figure 2. A detailed breakdown of the distribution of banks included in the sample, as well as a comprehensive list of bank specific efficiency scores can be found in the Appendix.

Fig. 2. Changes in Technical Efficiency Over Time

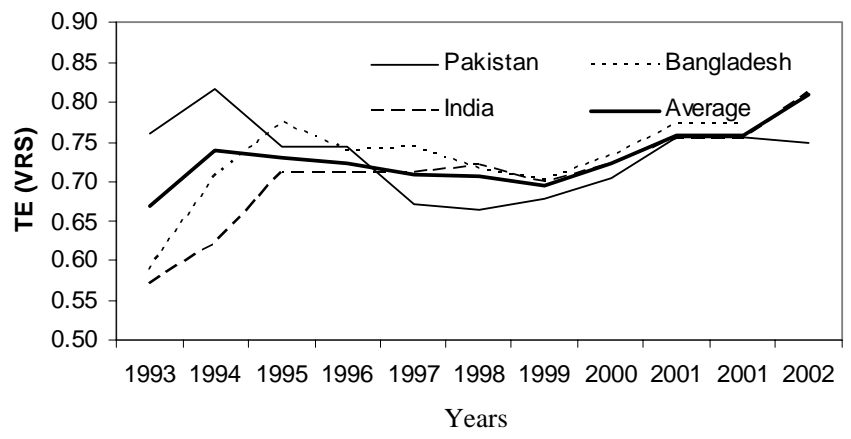

Figure 3 shows efficiency by type of business. On average, both 'non-bank' financial institutions and branches of the Central Bank in India appear to be doing well in the pre 1998 period, but both experience a decline in efficiency toward the end of the sample period. An important and interesting feature of the business is the convergence of efficiency in post 1998 period. Commercial banks appear to be achieving more stability than other banks in term of their efficiency scores throughout the sample period. Cooperative banks on the other side seem be consistently performing poorly compare to other banks before 1998, although they do seem to be catching up with other banks in the post deregulatory period. 
Fig. 3. Banks Efficiency: by Type of Business

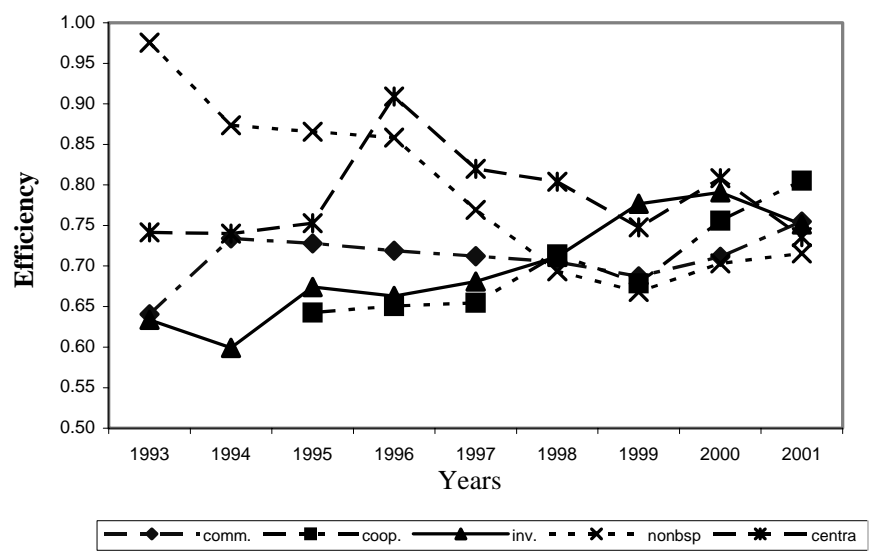

Figure 4 shows the efficiency score by the age of the business and type of ownership. Banks are categorised as old and new. Old banks are considered to be those established in the pre reform period (1990). There appears to be a very marginal difference in term of efficiency scores between public and private, as well as between old and new banks in the sample period.

Fig. 4. Banks Efficiency: by Age and Ownership of the Business

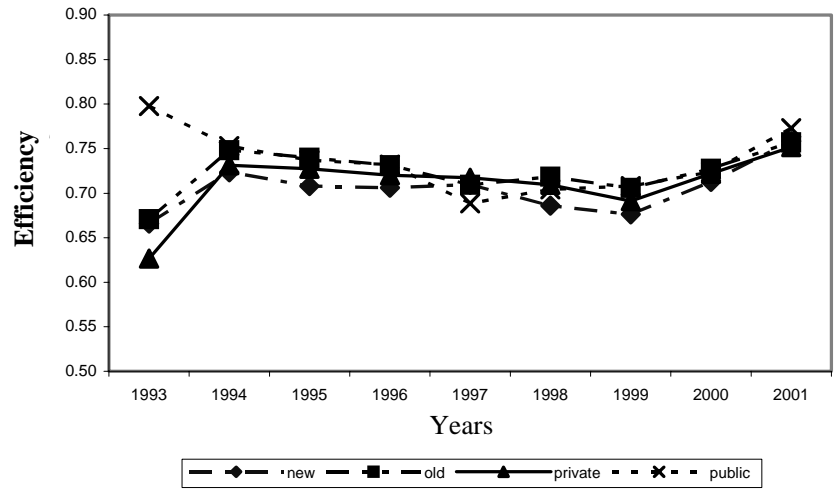

Figure 5 shows efficiency score by volume of business. Banks are categorised as small, medium or large as per their total assets. Very large and small banks appear to be performing well in term of efficiency score for the sample period 1994 to 1999. Over the entirety of the sample period, this diagram illustrates both a convergence in efficiency scores between banks of different sizes and, despite a 'blip' period from 1996-1998, also shows a slight increase in efficiency for banks of all sizesespecially from 1999 onwards. 
Fig. 5. Banks Efficiency, by Size of the Business

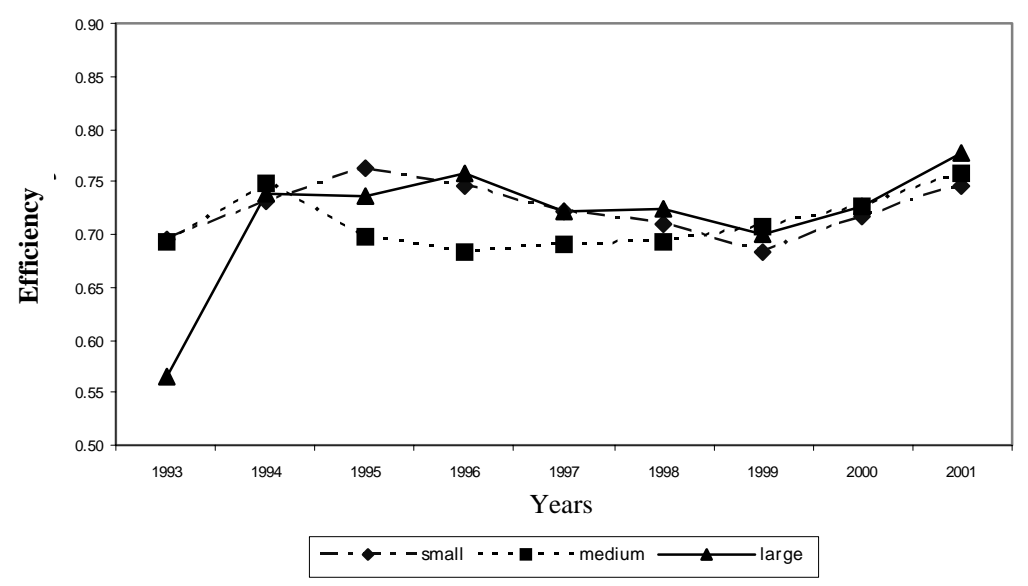

Figure 6 shows efficiency score on the basis of respective banks being listed on the stock exchanges of their respective countries. There appears to be very marginal difference in term of efficiency scores for listed and non-listed banks. However, in the post 1999 period, non-listed banks did perform slightly better compared to those which were listed.

Fig. 6. Banks Efficiency, by Listing of the Business in Stock Exchange.

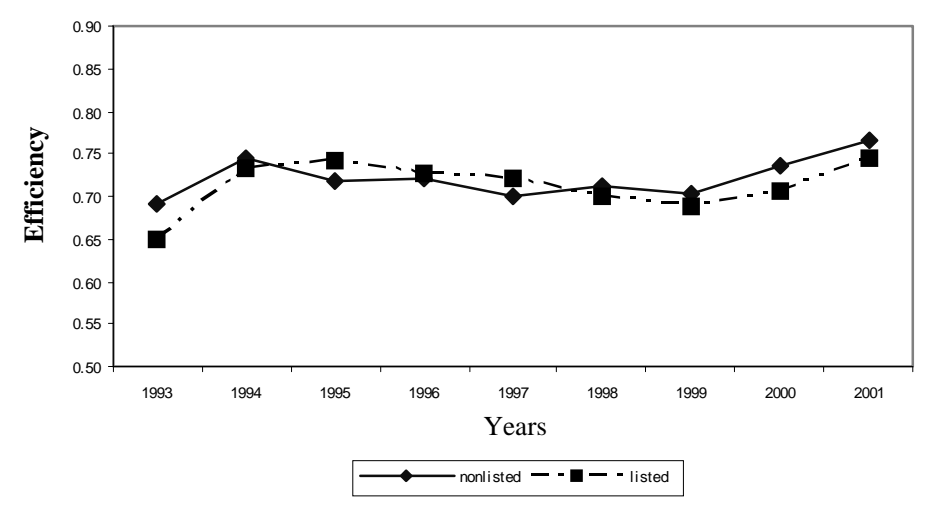

For much of the period, TFP estimates for banks in all of the countries under scrutiny were close to 1, displaying no great change from year to year (Figure 7). TFP for Bangladesh and India was greater than 1 at the start of the period (when the first round of deregulations took place) and also towards the end of the period (post 1998). For Pakistan, TFP increased after 1998, corresponding to the extensive policy of modernisation which took effect post 1997. 
Fig. 7. Changes in TFP Over Time

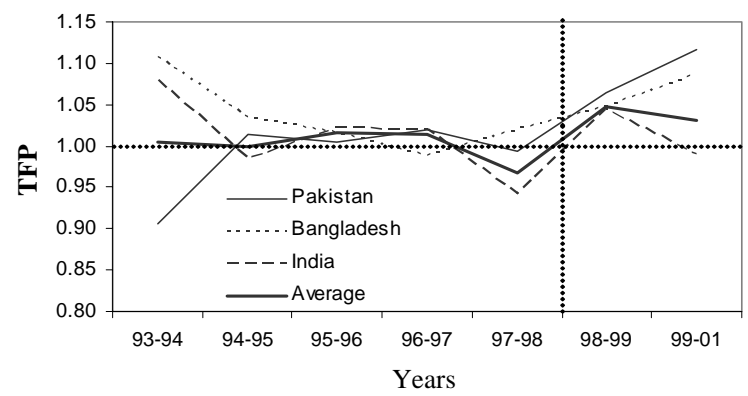

The components of TFP are illustrated in Figure 8, averaged over all three countries. Over much of the period, banks across the sample were becoming more efficient (i.e. getting closer to the frontier), with efficiency change values greater than 1. However, these efficiency improvements were offset by the fact that the frontier was contracting inwards over the same time period, with a technical change value of less than 1 . This inward shift of the frontier could be the result of macroeconomic conditions. There was a substantial outward shift in the frontier post 1998 following the period of modernisation. Average efficiency decreased, as not all banks shifted outwards at the same time (therefore, those that did not shift outwards became relatively less efficient).

Fig. 8. Components of TFP (Averaged Overall Countries)

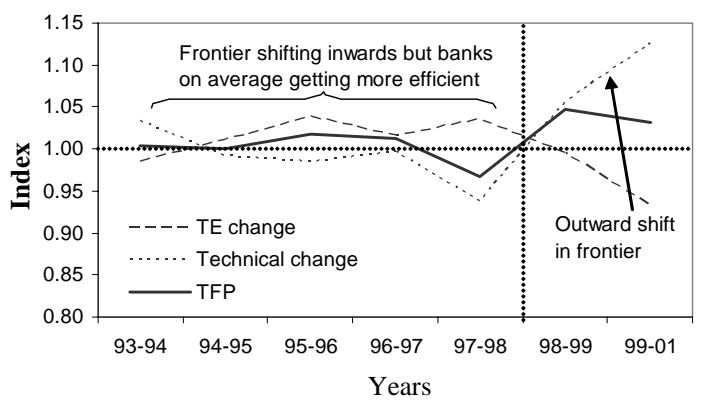

\section{VI.2. Tobit Analysis}

The results of the Panel Tobit regression can be found below in Table 4. Note that variables with a level of significance at or above the 1 percent are denoted with two asterisks $\left({ }^{* *}\right)$. A single asterisk $(*)$, in this specific instance, is used to denote a variable that is at, or very close to, the boundary of statistical significance at the 5 percent confidence interval. In terms of the Dummy Year Variable, a double asterisk denotes a time period of highly significant efficiency improvements, whereas a single asterisk denotes notable improvements. 
Table 4

Panel Tobit Regression Output

\begin{tabular}{|c|c|c|}
\hline Definition & Coefficient & Sig. \\
\hline \multicolumn{3}{|l|}{ Bank Characteristics } \\
\hline Bank equity capital divided by total assets & 0.0007 & 0.1800 \\
\hline Bank non earning assets divided by total assets** & -0.0011 & 0.0080 \\
\hline Bank net loans divided by total assets* & 0.0004 & 0.0550 \\
\hline Bank deposits divided by total assets & 0.0003 & 0.1390 \\
\hline Bank overhead expenditure divided by total assets & 0.0021 & 0.3440 \\
\hline Total cost to total asset & 0.0015 & 0.2710 \\
\hline \multicolumn{3}{|l|}{ Macroeconomic Indicators } \\
\hline GDP growth rate** & 0.0159 & 0.0000 \\
\hline Inflation rate (based on CPI) & -0.0039 & 0.3200 \\
\hline Real interest rate (interest rate minus inflation rate) & -0.0026 & 0.3620 \\
\hline Country share price index ${ }^{* *}$ & 0.0005 & 0.0000 \\
\hline Industrial production index & -0.0003 & 0.2020 \\
\hline \multicolumn{3}{|l|}{ Financial Structure Variables } \\
\hline $\begin{array}{l}\text { Total assets of largest three banks of the country divided by total } \\
\text { assets of the banking sector of the country }\end{array}$ & 0.0619 & 0.8420 \\
\hline Log of total assets & 0.0036 & 0.1480 \\
\hline Number of banks & -0.0005 & 0.2680 \\
\hline Bank credit divided by GDP** & 0.0249 & 0.0000 \\
\hline Stock Market Capitalisation Divided by GDP & 0.0014 & 0.5380 \\
\hline Dummy for Commercial Banks & 0.0115 & 0.2160 \\
\hline Dummy for Investment Banks & 0.0152 & 0.3260 \\
\hline Dummy Variable for Publicly Listed** & -0.0226 & 0.0010 \\
\hline Dummy Variable for India Public Sector Banks & -0.0045 & 0.6810 \\
\hline Dummy Variable for Pakistan Public Sector Banks & -0.0227 & 0.1170 \\
\hline \multicolumn{3}{|l|}{ Year Dummy Variables } \\
\hline Dummy Variable for India 1994 & -0.0124 & 0.8290 \\
\hline Dummy Variable for India $1995 * *$ & 0.1093 & 0.0990 \\
\hline Dummy Variable for India 1996* & 0.1713 & 0.0220 \\
\hline Dummy Variable for India 1997* & 0.1911 & 0.0010 \\
\hline Dummy Variable for India 1998* & 0.1873 & 0.0110 \\
\hline Dummy Variable for India 1999* & 0.1383 & 0.0030 \\
\hline Dummy Variable for India 2000 & 0.0177 & 0.7660 \\
\hline Dummy Variable for India 2001 & 0.0271 & 0.1810 \\
\hline Dummy Variable for Pakistan 1994 & -0.0239 & 0.2690 \\
\hline Dummy Variable for Pakistan 1995 & -0.0103 & 0.6110 \\
\hline Dummy Variable for Pakistan 1996 & -0.0137 & 0.4960 \\
\hline Dummy Variable for Pakistan 1997 & -0.0074 & 0.7110 \\
\hline Dummy Variable for Pakistan 1998** & 0.0367 & 0.0650 \\
\hline Dummy Variable for Pakistan 1999** & 0.0305 & 0.0540 \\
\hline Dummy Variable for Pakistan 2000* & 0.0275 & 0.0462 \\
\hline Dummy Variable for Pakistan 2001** & 0.0405 & 0.0560 \\
\hline Dummy Variable for Bangladesh 1994 & 0.0608 & 0.1200 \\
\hline Dummy Variable for Bangladesh 1995* & 0.1106 & 0.0090 \\
\hline Dummy Variable for Bangladesh 1996* & 0.0821 & 0.0100 \\
\hline Dummy Variable for Bangladesh $1997^{* *}$ & 0.0522 & 0.0680 \\
\hline Dummy Variable for Bangladesh 1998 & 0.0190 & 0.6440 \\
\hline Dummy Variable for Bangladesh 1999 & 0.0350 & 0.3260 \\
\hline Dummy Variable for Bangladesh 2000 & -0.0113 & 0.6890 \\
\hline Dummy Variable for Bangladesh 2001 & -0.0272 & 0.4210 \\
\hline Constant & 0.0660 & 0.7610 \\
\hline
\end{tabular}


The results displayed in Table 4, first and foremost, seem to confirm that which was established in the results of the TE VRS equation above. The most noticeable trend is observed in the yearly dummy variable section, illustrating a trend of efficiency improvement for all three countries over the period of the study. ${ }^{4}$ In the case of each country, there appears to be a specific time period in which efficiency levels dramatically increased. These are 1995 for both India and Bangladesh and 1998 for Pakistan. These years correspond to the periods immediately following deregulation for each respective country, and takes into account the significant deregulation which took place in Pakistan in 1997 (later than for the other two countries). The turn of the century lead to a slowdown in efficiency change for both India and Bangladesh, with a majority of the improvement taking place for these countries in the mid to late 1990s. Pakistan, however, continued to enjoy significant efficiency improvements right up until the end of the period of study. ${ }^{5}$

A majority of the 'Bank Characteristic' variables display the expected signs. The only exceptions are 'bank deposits divided by total assets' and 'bank overhead expenditure divided by total assets'. Three of the macroeconomic indicator variables display signs which are contrary to the expected, although the two variables from this category that do display the expected signs are strongly statistically significant (GDP growth and country share price index). The specific co-efficients suggest that improvements in efficiency experienced across the Indian sub-continent in the latter years of the study would have been influenced by macroeconomic conditions more than any other single factor.

All of the Financial Structure Variables display the expected signs, two of which are strongly statistically significant (Bank credit divided by GDP and the dummy variable reflecting publicly listed firms). The implications of these results are discussed in Table 2.

\section{CONCLUSION}

This paper has sought to examine the effect of significant modernisation and deregulation upon technical efficiency within the Indian sub-continent over the time period 1993-2002. The results indicate that the three countries in question more or less converge in terms of efficiency at the end of the period. Specifically, the greatest trends in terms of efficiency gains over the course of the sample can be seen in India and Bangladesh-both of which experience dramatic and continued improvements in efficiency through out the entire deregulatory period (although the rate of improvement does slow after the turn of the century). Pakistan experiences a delay in experiencing these same trends, suffering from a number of efficiency decreases in the middle of the period. Subsequent to the major Pakistani reforms in 1997, efficiency levels then recover to levels which are comparable to those experienced in India and Bangladesh, while efficiency improvements remain strong even in the latter years of the study. 
Appendix

Number of Banks by Country and Type

Pakistan

Commercial

Investment

2

Specialised Govt.

Bangladesh

Commercial

Investment

Specialised Govt.

India

Commercial

Investment

Specialised Govt.

Cooperatives

NBFI 


\begin{tabular}{|c|c|c|c|}
\hline \multicolumn{4}{|c|}{ Individual Bank Efficiency Scores } \\
\hline Country & Bank Name & Type of Bank & Efficiency Score \\
\hline Pakistan & Agricultural development bank of Pakistan & Specialised & 0.802 \\
\hline Pakistan & Al faysal bank & Commercial & 0.665 \\
\hline Pakistan & Allied bank & Commercial & 0.765 \\
\hline Pakistan & Askari bank & Commercial & 0.762 \\
\hline Pakistan & Bank alhabib & Commercial & 0.702 \\
\hline Pakistan & Bank alfalah & Commercial & 0.664 \\
\hline Pakistan & Bank Khyber & Commercial & 0.710 \\
\hline Pakistan & Bank of Punjab & Commercial & 0.674 \\
\hline Pakistan & Bankers equity & Specialised & 0.752 \\
\hline Pakistan & Bolan bank & Commercial & 0.662 \\
\hline Pakistan & Crescent bank & Investment & 0.682 \\
\hline Pakistan & Faysal bank & Commercial & 0.713 \\
\hline Pakistan & First international investment bank & Investment & 0.648 \\
\hline Pakistan & First women bank & Commercial & 0.626 \\
\hline Pakistan & Habib bank & Commercial & 0.837 \\
\hline Pakistan & Industrial development bank of Pakistan & Specialised & 0.549 \\
\hline Pakistan & Indus bank & Commercial & 0.719 \\
\hline Pakistan & Muslim commercial bank & Commercial & 0.786 \\
\hline Pakistan & Metropolitan bank & Commercial & 0.855 \\
\hline Pakistan & National bank of Pakistan & Commercial & 0.828 \\
\hline Pakistan & PICIC commercial bank & Commercial & 0.765 \\
\hline Pakistan & Pakistan industrial credit and investment corp. & Specialised & 0.626 \\
\hline Pakistan & Platinum commercial bank & Commercial & 0.691 \\
\hline Pakistan & Prime commercial bank & Commercial & 0.700 \\
\hline Pakistan & Saudipak commercial bank & Commercial & 0.581 \\
\hline Pakistan & Soneri bank & Commercial & 0.798 \\
\hline Pakistan & Union bank & Commercial & 0.683 \\
\hline Pakistan & United bank & Commercial & 0.858 \\
\hline Bangladesh & Agrani bank & Commercial & 0.719 \\
\hline Bangladesh & Al-arafah islami bank & Commercial & 0.818 \\
\hline Bangladesh & Arab Bangladesh bank ltd. & Commercial & 0.731 \\
\hline Bangladesh & Bangladesh krishi bank & Specialised & 0.631 \\
\hline Bangladesh & Bangladesh shilpa bank & Specialised & 0.555 \\
\hline Bangladesh & Bangladesh shilpa rin sang & Commercial & 0.819 \\
\hline Bangladesh & Bank Asia ltd. & Commercial & 0.685 \\
\hline Bangladesh & Bank of small industries and commerce ltd. & Commercial & 0.902 \\
\hline Bangladesh & City bank ltd. & Commercial & 0.670 \\
\hline Bangladesh & Dhaka bank ltd. & Commercial & 0.730 \\
\hline Bangladesh & Dutch-Bangla bank ltd. & Commercial & 0.749 \\
\hline Bangladesh & Eastern bank ltd. & Commercial & 0.812 \\
\hline Bangladesh & Export import bank of Bangladesh ltd. & Commercial & 0.715 \\
\hline Bangladesh & First security bank ltd. & Commercial & 0.618 \\
\hline Bangladesh & International finance investment and comm. & Commercial & 0.775 \\
\hline Bangladesh & Islami bank Bangladesh ltd. & Investment & 0.807 \\
\hline
\end{tabular}


Appendix Table-(Continued)

\begin{tabular}{|c|c|c|c|}
\hline Bangladesh & Janata bank & Commercial & 0.657 \\
\hline Bangladesh & Mercantile bank ltd. & Commercial & 0.762 \\
\hline Bangladesh & Mutual trust bank & Commercial & 0.625 \\
\hline Bangladesh & National bank ltd. & Commercial & 0.900 \\
\hline Bangladesh & National credit and commerce bank ltd. & Commercial & 0.702 \\
\hline Bangladesh & One bank ltd. & Commercial & 0.593 \\
\hline Bangladesh & Premier bank ltd. & Commercial & 0.656 \\
\hline Bangladesh & Prime bank ltd. & Commercial & 0.835 \\
\hline Bangladesh & Pubali bank ltd. & Commercial & 0.683 \\
\hline Bangladesh & Rupali bank ltd. & Commercial & 0.600 \\
\hline Bangladesh & Social investment bank ltd. & Investment & 0.701 \\
\hline Bangladesh & Sonali bank & Commercial & 0.684 \\
\hline Bangladesh & Southeast bank ltd. & Commercial & 0.676 \\
\hline Bangladesh & Standard bank ltd. & Commercial & 0.594 \\
\hline Bangladesh & United commercial bank ltd. & Commercial & 0.759 \\
\hline India & Allahabad bank & Commercial & 0.714 \\
\hline India & Andhra bank & Commercial & 0.679 \\
\hline India & Apex co-operative bank & Co-operative & 0.715 \\
\hline India & Baharat overseas bank ltd. & Commercial & 0.615 \\
\hline India & Bank of Baroda & Commercial & 0.955 \\
\hline India & Bank of Indian & Commercial & 0.924 \\
\hline India & Bank of Madura ltd. & Commercial & 0.695 \\
\hline India & Bank of Maharasthra & Commercial & 0.688 \\
\hline India & Bank of syrian ltd. & Commercial & 0.752 \\
\hline India & Bank of Rajasthan ltd. & Commercial & 0.628 \\
\hline India & Barclays bank plc-Indian branches & Commercial & 0.625 \\
\hline India & Benares state bank & Specialised & 0.560 \\
\hline India & Bombay mercantile co-operative bank ltd. & Co-operative & 0.548 \\
\hline India & Canara bank & Commercial & 0.947 \\
\hline India & Catholic syrian bank ltd. & Commercial & 0.589 \\
\hline India & Central bank of India & Commercial & 0.862 \\
\hline India & Centurion bank ltd. & Commercial & 0.636 \\
\hline India & Citizencredit co-op bank ltd. & Co-operative & 0.575 \\
\hline India & City union bank ltd. & Commercial & 0.650 \\
\hline India & Corporation bank ltd. & Commercial & 0.788 \\
\hline India & Cosmos co-op bank & Co-operative & 0.568 \\
\hline India & Credit lyonnais, Indian branches & Commercial & 0.695 \\
\hline India & Dena bank & Commercial & 0.692 \\
\hline India & Development credit bank ltd. & Co-operative & 0.698 \\
\hline India & Dhanalakshrmi bank ltd. & Commercial & 0.562 \\
\hline India & Discount and finance house of India & Investment & 0.962 \\
\hline India & Export-import bank of India & Specialised & 0.896 \\
\hline India & Federal bank ltd. & Commercial & 0.662 \\
\hline India & Ganesh bank of kurundwad ltd. & Commercial & 0.519 \\
\hline India & Global trust bank ltd. & Commercial & 0.777 \\
\hline
\end{tabular}


Appendix Table-(Continued)

\begin{tabular}{|c|c|c|c|}
\hline India & HDFC bank ltd. & Commercial & 0.784 \\
\hline India & ICICI bank ltd. & Commercial & 0.751 \\
\hline India & ICICI securities and finance company ltd. & Investment & 0.875 \\
\hline India & IDBI bank ltd. & Commercial & 0.647 \\
\hline India & IFCI ltd. & Non-bank FI & 0.765 \\
\hline India & Indian bank & Commercial & 0.698 \\
\hline India & Industrial bank ltd. & Commercial & 0.725 \\
\hline India & Industrial credit and investment corp. Of India & Specialised & 0.962 \\
\hline India & Industrial development bank of India & Specialised & 0.981 \\
\hline India & Industrial investment bank of India & Investment & 0.691 \\
\hline India & Infrastructure development finance co ltd. & Investment & 1.000 \\
\hline India & Infrastructure leasing and financial services ltd. & Non-bank FI & 1.000 \\
\hline India & Jammu and Kashmir bank ltd. & Commercial & 0.705 \\
\hline India & Karur Vysya bank ltd. & Commercial & 0.712 \\
\hline India & Lakshmi vilas bank ltd. & Commercial & 0.683 \\
\hline India & Lord Krishna bank ltd. & Commercial & 0.606 \\
\hline India & Maharashtra co-operative bank & Co-operative & 0.594 \\
\hline India & Maharashtra state financial corporation & Commercial & 0.527 \\
\hline India & Natinital bank ltd. & Commercial & 0.569 \\
\hline India & National bank for agriculture and rural develop. & Specialised & 0.859 \\
\hline India & National housing bank & Commercial & 0.869 \\
\hline India & Nedungadi bank ltd. & Commercial & 0.594 \\
\hline India & Oriental bank of commerce & Commercial & 0.756 \\
\hline India & Punjab and Sindh bank & Commercial & 0.637 \\
\hline India & Punjab national bank & Commercial & 0.944 \\
\hline India & Ratnakar bank ltd. & Commercial & 0.594 \\
\hline India & SBI commercial and international bank ltd. & Commercial & 0.629 \\
\hline India & Securities trading corporation of India ltd. & Investment & 0.999 \\
\hline India & Small industries development bank of India & Specialised & 0.936 \\
\hline India & South Indian bank ltd. & Commercial & 0.615 \\
\hline India & State bank of Bikaner and Jaipur & Commercial & 0.719 \\
\hline India & State bank of Hyderabad & Commercial & 0.743 \\
\hline India & State bank of India & Commercial & 0.604 \\
\hline India & State bank of Indore & Commercial & 0.713 \\
\hline India & State bank of Mysore & Commercial & 0.684 \\
\hline India & State bank of Patiala & Commercial & 0.736 \\
\hline India & State bank of Saurashtra & Commercial & 0.694 \\
\hline India & State bank of Travancore & Commercial & 0.676 \\
\hline India & Syndicate bank & Commercial & 0.799 \\
\hline India & Tamilnad mercentile bank & Commercial & 0.694 \\
\hline India & Times bank & Commercial & 0.627 \\
\hline India & UCO bank & Commercial & 0.721 \\
\hline India & Union bank of India & Commercial & 0.824 \\
\hline India & United bank of India & Commercial & 0.676 \\
\hline India & United western bank & Commercial & 0.660 \\
\hline India & Uti bank & Commercial & 0.692 \\
\hline India & Vijaya bank & Commercial & 0.656 \\
\hline India & Vysya bank ltd. & Commercial & 0.705 \\
\hline India & Indian overseas bank & Commercial & 0.742 \\
\hline India & Karnataka bank ltd. & Commercial & 0.677 \\
\hline
\end{tabular}




\section{REFERENCES}

Aignes, D. J., C. A. K. Lovell, and P. Schmidt (1977) Formulation and Estimation of Stochastic Production Function Models. Journal of Econometrics 6, 21-37.

Atkinson, S. E., and D. Primon (2002) Stochastic Estimation of Firm Technology, Inefficiency and Productivity Growth Using Shadow Cost and Distance Functions. Journal of Econometrics 108, 203-225.

Banker, R. D., and H. Chang (2005) The Super-efficiency Procedure for Outlier Identification, Not for Ranking Efficient Units. European Journal of Operational Research. In Press, Available online 24 August 2005.

Bauer, P. W., A. N. Berger, and D. B. Humphrey (1993) Efficiency and Productivity Growth in U.S. Banking. In H. O. Fried, C. A. Lovell, and S. S. Schmidt The Measurement of Productive Efficiency: Techniques and Applications. Oxford University Press, pp. 386-413.

Berg, S. A., F. R. Foersund, and E. S. Jansen (1992) Malmquist Indices of Productivity Growth During the Deregulation of Norwegian Banking 1980-89. Scandinavian Journal of Economics 94, 211-228.

Berger, A. N., and D. B. Humphrey (1992) Measurement and Efficiency Issues in Commercial Banking. In Output Measurement in the Service Sectors. National Bureau of Economic Research Studies in Income and Wealth. Vol. 56. Chicago: University of Chicago Press.

Berger, A. N., and D. B. Humphrey (1997) Efficiency of Financial Institutions: International Survey and Directions for Future Research. European Journal of Operational Research 98, 175-212.

Berger, A. N., and L. J. Mester (2001) Explaining the Dramatic Changes in Performance of U.S. Banks: Technological Change, Deregulation and Dynamic Changes in Competition. Journal of Financial Intermediation. (Forthcoming.)

Bonnaccorsi di Patti, B., and D. C. Hardy (2005) Financial Sector Liberalisation, Bank Privatisation and Efficiency: Evidence from Pakistan. Journal of Banking and Finance 29, 2381-2406.

Canhoto, A., and J. Dermine (2003) A Note on Banking Efficiency in Portugal, New vs Old Banks. Journal of Banking and Finance 27, 2087-2098.

Carvallo, O., and A. Kasman (2005) Cost Efficiency in the Latin American and Caribbean Banking Systems. Journal of International Financial Institutions and Money 15:1, 55-72.

Christopolous, D. K., S. E. G. Lolos, and E. G. Tsionas (2002) Efficiency of the Greek Banking System in View of the EMU: A Heteroscedastic Stochastic Frontier Approach. Journal of Policy Making 24, 813-829.

Cooper, W. W., S. Kumbhakar, R. M. Thrall, and X. Yu (1995) DEA and Stochastic Frontier Analyses of the 1978 Chinese Economic Reforms. Socio-econ Plann. Sci. 29:2, 85-112. 
Cuesta, R. A., and L. Orea (2002) Mergers and Technical Efficiency in Spanish Savings Banks: A Stochastic Distance Function Approach. Journal of Banking and Finance 26, 2231-2247.

Davidson, Russell, and James G. MacKinnon (2004) Econometric Theory and Methods. New York: Oxford University Press.

Fare, R., Grosskopf S. Grifell-Tatje, and C. A. Knox-Lovell (1997) Biased Technical Change and the Malmquist Productivity Index. Scandinavian Journal of Economics 99:1, 119-127.

Fuckuyama, H., and W. L. Weber (2002) Estimating Output Allocative Efficiency and Productivity Change: Application to Japanese Banks. European Journal of Operational Research 137, 177-190.

Gilbert, R. A., and P. W. Wilson (1998) Effects of Deregulation on the Productivity of Korean Banks. Journal of Economics and Business 50, 133-155.

Heshmanti, A., S. C. Kumbakhar, and L. Hjalmarsson (1995) Efficiency of the Swedish Pork Industry: A Farm Level Study Using Rotating Panel Data 19761988. European Journal of Operational Research 80, 519-533.

Hitomi, K. (2004) Efficiency Analysis of Japan's Industry and Manufacturing. Technovation 24, 741-748.

Kashani, H. A. (2005) Regulation and Efficiency: An Empirical Analysis of the United Kingdom Continental Shelf Petroleum Industry. Energy Policy 33, 915925.

Kazmi, H. Shabbir (2002) Commercial Banks, the New Era of Consolidation. Pakistan Economist, July 15-21.

Kumbhakar, S. C. (1996) A Farm-level Study of Labour Use and Efficiency Wages in Indian Agriculture. Journal of Econometrics 72, 177-195.

Khumbhakar, S. C., A. Lozano-Vivas, C. A. Knox-Lovell, and I. Hasan (2001) The Effects of Deregulation on the Performance of Financial Institutions: The Case of Spanish Savings Banks. Journal of Money, Credit and Banking 33:1, 101-120.

Kumbhakar, S. C., and S. Sarkar (2003) Deregulation, Ownership and Productivity Growth in the Banking Industry: Evidence from India. Journal of Money, Credit and Banking 35:3, 403-424.

Mendes, V., and J. Rebelo (1999) Productivity Efficiency, Technological Change and Productivity in Portuguese Banking. Applied Financial Economics 9:5, 513521.

Meeusen, W., and J. Van den Broeck (1977) Efficiency Estimation from CobbDouglas Production Functions with Composed Error. International Economic Review 18:2, 435-444.

Podder, J., and A. A. Mamun (2004) Loan Loss Provisioning System in Bangladesh Banking: A Critical Analysis. Managerial Auditing Journal 19:6, 729-740.

Resti, A. (1998) Regulation can Foster Mergers, can Mergers Foster Efficiency? The Italian Case. Journal of Economics and Business 50:2, 157-169. 
Rossi, M. A. (2001) Technical Change and Efficiency Measures: the Post Privatisation in the Gas Distribution Sector in Argentina. Energy Economics 23, 295-304.

Sathe, M. (2003) Efficiency of Banks in a Developing Economy: the Case of India. European Journal of Operational Research 148, 662-671.

Sayeed, Y., M. Bari, M. M. Rahman, W. A. Azad, M. Moniruzzaman, and L. M. Shilpi (2002) Swinging Banking: Not Very Promising, Bangladesh Research, Asset and Investment Management Services of Bangladesh Limited.

Sena, V. (2004) The Determinants of Firm Performance: Can Finance Constraints Improve Technical Efficiency? European Journal of Operational Research.

Shepard, R. W. (1970) Theory of Cost and Production Functions. Princeton, New Jersey: Princeton University Press.

Wheelock, D. C., and P. W. Wilson (1999) Technical Progress, Inefficiency and Productivity Change in U.S. Banking, 1984-1993. Journal of Money, Credit and Banking 31, 212-234.

Zaim, O. (1995) The Effect of Financial Liberalisation on the Efficiency of Turkish Commercial Banks. Applied Financial Economics 5:4, 257-264. 


\section{Comments}

The development of a financially sound, banking system is vital both to macroeconomic stability and to favourable long-term growth prospects. The banking industry reforms therefore, constituted a large part of the financial sector reforms introduced worldwide in early 1980s. These reforms mainly comprised of the liberalisation and deregulation of the most heavily regulated banking industry. Thus making the analysis of the efficiency and productivity of the banking sector in the post reform period an important issue for the researchers. By focusing on the developing economies of India, Pakistan and Bangladesh, this paper, is a valuable addition to the ongoing rigorous research in this area.

A three pronged approach has been used for efficiency measurement within the Indian sub-continent. These are the Malmquist index, which attributes productivity change to technical change index and a technical efficiency index, variable return to scale output oriented DEA, which has been developed over the last two decades with over a thousand papers applying the method to different fields ranging from banking to education and a panel Tobit Analysis of the resultant DEA scores, which is a recent development in the DEA.

Figure 4 holds the conclusion of the paper, which states that with efficiency change values greater than one, banks in all three countries have been becoming more efficient. However this is offset by the technical change value less than one, leading the authors to conclude that the inward contracting of the total factor productivity frontier could be the result of macroeconomic conditions.

There are a few comments which can improve the standard of the paper.

We start off with data section of the paper.

A brief discussion on the data source of each country, along with a list of the number and types of the banks of each country (probably in the appendix) would improve the design of the paper. In Section VI, the authors have indicated that the exclusion rule decreased the sample size from 1006 to 898, which is insufficient information.

The analysis covers the period 1993-2001; a slight justification of the choice of this period would help in the understanding of the conclusion drawn by the authors.

The choice of inputs and outputs is still an ongoing debate for DEA analysis. The relevance of the use of particular set of inputs and output for the Indian subcontinent is required. Another set of inputs and outputs can be used to check the robustness of results. 
The method of maximum likelihood can be used to estimate the Tobit (censored) regression models. A brief description of the estimation technique used for the coefficients reported in Section VI.2, should be mentioned in the methodology section as per standard practice.

While all the variables are measured at level, a brief interpretation of the coefficient of total assets-a measure of financial structure variable which has been constructed as log needs econometric explanation.

In addition to the variables listed in Table 3. a direct effect of the regulations can be obtained using any regulatory variable along with an index to capture the effect of legal/institutional quality.

A few examples from literature would strengthen authors' application of "exclusion rule" in the Section VI.1.

DEA uses linear programming to calculate the relative efficiency scores of each DMU. It tells the user which of the DMUs in the sample are efficient and which are not. This ability of DEA gives it an edge over the other methods. A table of efficiency scores of each of the bank included in the sample will help to identify the possible peers or role models of the Indian sub-continent.

Table 3 in Section VI.2, illustrates a trend of efficiency change over the period of analysis for each country. The same also reports dummies for commercial banks, investment banks and publicly listed banks for India and Pakistan. A brief explanation of the role of the bank types as a co-variate of efficiency, would provide depth to the analysis.

Technical change or a shift in production frontier is a long-run phenomenon triggered mainly by research and development activities. The trained management, automation of, and the use of electronic access to banking services can be helpful in shifting the technical change frontier outward. The decline in the potential output, given the inputs in this case, can also be attributed to the transition phase which follows policy reforms. That highlighting an important area for further research. One possibility is to use segregated analysis of each country using decomposition of all the data, by the ownership of public, private, and foreign-owned banks.

Pakistan Institute of Development Economics,

Saba Anwar Islamabad. 